\title{
PENGARUH PENDAPATAN ASLI DAERAH, DANA ALOKASI UMUM, DAN DANA ALOKASI KHUSUS TERHADAP BELANJA MODAL \\ (Studi Kasus Pada Pemerintah Daerah Kabupaten dan Kota di Provinsi Sulawesi Utara) HENRI PAULUS GERUNGAN ${ }^{1}$, DAVID PAUL ELIA SAERANG ${ }^{2}$, VENTJE ILAT ${ }^{3}$
}

\author{
Program Magister Akuntansi, Fakultas Ekonomi dan Bisnis Universitas Sam Ratulangi \\ Email: gerunganhenry@gmail.com
}

\begin{abstract}
The main purpose of regional autonomy implementation is to improve public services and to develop the regional economy in Indonesia. Due to limited resources, local government should be able to allocate the earning income for productive output. However, in fact, the local government tends to allocate the income for Operating Expenditures. This research aims to analyze the effects of Regional Real Income, General Allocation Fund, and Special Allocation Fund to the Capital Expenditure. This is a quantitative research. The data used in this study research were APBD budget District and City in North Sulawesi Province from 2011 to 2015. The analysis method applied in this study research was multiple regression analysis and supported by SPSS Version 23. The result shows that Regional Real Income and the Special Allocation Fund influence positively and significantly Capital Expenditures. On the other hand, the General Allocation Fund does not affect Capital Expenditure.
\end{abstract}

Keywords: Regional Real Income, General Allocation Fund, Special Allocation Fund, Capital Expenditure.

Abstrak. Tujuan utama pelaksanaan otonomi daerah adalah untuk meningkatkan pelayanan publik (public service) dan memajukan perekonomian daerah di Indonesia. Dengan sumber daya yang terbatas, Pemerintah Daerah harus dapat mengalokasikan penerimaan yang diperoleh untuk belanja daerah yang bersifat produktif. Namun faktanya Pemerintah Daerah cenderung mengalokasikan pendapatan untuk keperluan belanja operasi. Penelitian ini bertujuan untuk menganalisis pengaruh Pendapatan Asli Daerah, Dana Alokasi Umum, dan Dana Alokasi Khusus terhadap Belanja Modal. Metode penelitian yang digunakan adalah metode kuantitatif. Adapun data yang digunakan adalah data APBD Kabupaten dan Kota di Provinsi Sulawesi Utara Tahun 2011 sampai 2015. Metode analisis yang digunakan dalam penelitian ini adalah regresi berganda dengan menggunakan bantuan aplikasi SPSS versi 23. Hasil penelitian menunjukan Pendapatan Asli Daerah, dan Dana Alokasi Khusus berpengaruh positif dan signifikan terhadap belanja modal. Sedangkan Dana Alokasi Umum tidak berpengaruh terhadap Belanja Modal.

Kata Kunci : Pendapatan Asli Daerah, Dana Alokasi Umum, Dana Alokasi Khusus, Belanja Modal.

\section{Pendahuluan}

Kemajuan perkembangan daerah di Indonesia semakin pesat, seiring dengan adanya daerah baru dalam pelaksanaan otonomi daerah dan disentralisasi fiskal. Kebijakan tentang otonomi daerah di wilayah Negara Kesatuan Republik Indonesia (NKRI), yang dikukuhkan dengan undang-undang (UU) telah membawa konsekuensi tersendiri bagi daerah untuk bisa melaksanakan pembangunan disegala bidang, dengan harapan dapat dilaksanakan secara mandiri oleh daerah.

Tujuan utama pelaksanaan otonomi daerah adalah untuk meningkatkan pelayanan publik (public service) dan memajukan perekonomian daerah di Indonesia. Pelaksanaan otonomi daerah dan desentralisasi fiskal, pada dasarnya terkandung tiga misi utama yaitu: (1) meningkatkan kualitas dan kuantitas pelayanan publik dan kesejahteraan masyarakat; (2) 
menciptakan efisiensi dan efektifitas pengelolaan sumber daya daerah; dan (3) memberdayakan dan menciptakan ruang bagi masyarakat (publik) untuk berpatisipasi dalam pembangunan (Mardiasmo, 2009:59).

Anggaran daerah merupakan rencana keuangan yang dijadikan pedoman oleh Pemerintah Daerah dalam memberikan pelayanan kepada publik. Di Indonesia, anggaran daerah disebut dengan Anggaran Pendapatan dan Belanja Daerah (APBD). Seluruh penerimaan dan pengeluaran Pemerintah Daerah baik dalam bentuk uang, barang dan jasa pada tahun anggaran harus dianggarkan dalam APBD Komponen APBD terdiri dari Pendapatan Daerah, Belanja/Pengeluaran Daerah yang digunakan untuk keperluan penyelenggaraan tugas pemerintah di daerah dan pembiayaan Anggaran (Pembiayaan Defisit) yang digunakan untuk menutup defisit Anggaran Pemerintah Daerah. Dengan adanya otonomi daerah, pemerintah dituntut untuk dapat mengelola keuangan daerahnya dengan baik dan efektif (Kawendar dkk, 2008).

Pemerintah Daerah mengalokasikan dana dalam bentuk anggaran belanja modal dalam APBD untuk menambah aset tetap. Menurut Peraturan Pemerintah No. 71 Tahun 2010, Belanja Modal didefinisikan sebagai pengeluaran anggaran dalam pencapaian asset tetap serta asset lainnya yang dapat memberikan dampak positif lebih dari satu periode akuntansi. Belanja modal meliputi belanja modal untuk perolehan tanah, gedung dan bangunan, peralatan, dan aset tak berwujud. Menurut PP No. 71 Tahun 2010 aset tetap adalah aset berwujud yang mempunyai masa manfaat lebih dari 12 (dua belas) bulan untuk digunakan dalam kegiatan pemerintah atau dimanfaatkan oleh masyarakat umum. Aset tetap yang dimiliki Pemerintah Daerah dari belanja modal merupakan syarat utama dalam memberikan pelayanan publik. Untuk menambah aset tetap, Pemerintah Daerah mengalokasikan dana dalam bentuk anggaran belanja modal dalam APBD sesuai dengan prioritas anggaran dan pelayanan publik yang memberikan dampak jangka panjang secara finansial. Aset tetap diklasifikasikan berdasarkan kesamaan dalam sifat atau fungsinya dalam aktivitas operasi entitas.

Klasifikasi aset tetap yang digunakan menurut PP No. 24 Tahun 2010 yaitu tanah, peralatan dan mesin, gedung dan bangunan, jalan, irigasi, dan jaringan, aset tetap lainnya, konstruksi dalam pengerjaan. Pemanfaatan belanja lebih baik dialokasikan untuk hal-hal produktif, misalnya untuk melakukan aktivitas pembangunan, kemudian penerimaan pemerintah hendaknya lebih banyak untuk program-program layanan publik, pendapat ini menyiratkan pentingnya mengalokasikan belanja untuk berbagai kepentingan publik (Darwanto dan Yustikasari, 2007).

Permasalahan yang dihadapi Pemerintah Daerah dalam organisasi sektor publik adalah mengenai pengalokasian anggaran. Pengalokasian anggaran merupakan jumlah alokasi dana yang digunakan untuk masing-masing program kegiatan. Dengan sumber daya yang terbatas, Pemerintah Daerah harus dapat mengalokasikan penerimaan yang diperoleh untuk belanja daerah yang bersifat produktif. Belanja daerah merupakan perkiraan beban pengeluaran daerah yang dialokasikan secara adil dan merata agar relatif dapat dinikmati oleh seluruh kelompok masyarakat tanpa diskriminasi, khususnya dalam pemberian pelayanan umum (Kawendar dkk, 2008). Namun faktanya Pemerintah Daerah dalam pengalokasian pendapatan daerah cenderung digunakan untuk keperluan belanja operasi. Hal tersebut dapat dilihat dari Laporan Realisasi APBD pada Pemerintah Daerah Provinsi Sulawesi Utara tahun 2015. 


\section{Perbandingan Belanja Operasi dan Belanja Modal Provinsi Sulawesi Utara Tahun 2015}

(dalam jutaan rupiah)

\begin{tabular}{|c|c|c|c|c|c|}
\hline Kab/Kota & $\begin{array}{c}\text { Belanja } \\
\text { Operasi }\end{array}$ & $\begin{array}{c}\text { Belanja } \\
\text { Modal }\end{array}$ & $\begin{array}{c}\text { Total } \\
\text { Belenja }\end{array}$ & $\begin{array}{c}\text { \% Belanja } \\
\text { Operasi }\end{array}$ & $\begin{array}{c}\text { \% Belanja } \\
\text { Modal }\end{array}$ \\
\hline Bolmong & 189.432 & 181.810 & 371.242 & 51,02 & 48,97 \\
\hline Minahasa & 154.392 & 132.783 & 287.175 & 53,76 & 46,23 \\
\hline Sangihe & 178.422 & 123.650 & 302.072 & 59,06 & 40,93 \\
\hline Talaud & 119.443 & 188.846 & 308.289 & 38,74 & 61,25 \\
\hline Minsel & 172.706 & 156.920 & 329.627 & 52,39 & 47,60 \\
\hline Minut & 190.213 & 129.080 & 319.293 & 59,57 & 40,42 \\
\hline Bolmut & 129.043 & 141.447 & 270.490 & 47,70 & 52,29 \\
\hline Sitaro & 126.292 & 146.548 & 272.840 & 46,28 & 53,71 \\
\hline Mitra & 117.631 & 181.010 & 298.641 & 39,38 & 60,61 \\
\hline Bolsel & 113.927 & 157.356 & 271.283 & 41,99 & 58,00 \\
\hline Boltim & 122.463 & 158.790 & 281.253 & 43,54 & 56,45 \\
\hline Manado & 392.085 & 219.307 & 611.392 & 64,13 & 35,87 \\
\hline Bitung & 193.120 & 103.432 & 296.553 & 65,12 & 34,87 \\
\hline Tomohon & 145.774 & 119.918 & 265.692 & 54,86 & 45,13 \\
\hline Kotamobagu & 134.976 & 139.645 & 274.621 & 49,15 & 50,85 \\
\hline Sumber:Laporan
\end{tabular}

Sumber : Laporan Realisasi APBD Provinsi Sulawesi Utara Tahun 2015

Berdasarkan tabel 1.1 dapat dilihat bahwa persentase belanja operasi lebih besar daripada persentase belanja modal, dimana ada 8 kabupaten/kota yang presentase belanja operasi lebih besar daripada belanja modal dan hanya 7 kabupaten/kota yang presentase belanja modal lebih besar daripada belanja operasi pada Pemerintah Kab/Kota di Provinsi Sulawesi Utara, dengan kata lain aktivitas belanja yang dilakukan oleh Pemerintah Kab/Kota di Provinsi Sulawesi Utara cenderung banyak digunakan untuk belanja operasi daripada belanja modal. Oleh karena itu, dalam upaya meningkatkan kualitas pelayanan publik, pemerintah daerah seharusnya mengubah komposisi belanjanya, yang selama ini belanja daerah lebih banyak digunakan untuk belanja operasi yang relatif kurang produktif.

Berdasarkan latar belakang diatas penulis tertarik melakukan penelitian yang berjudul Pengaruh Pendapatan Asli Daerah, Dana Alokasi Umum, dan Dana Alokasi Khusus terhadap Belanja Modal (Studi Kasus pada Pemerintah Daerah Kabupaten dan Kota di Provinsi Sulawesi Utara).

\section{Rumusan Masalah}

Berdasarkan uraian pada latar belakang di atas, maka dalam penelitian ini dapat dirumuskan permasalahan sebagai berikut :

1. Apakah pendapatan asli daerah (PAD) berpengaruh positif dan signifikan terhadap besarnya Belanja Modal?

2. Apakah dana alokasi umum (DAU) berpengaruh positif dan signifikan terhadap besarnya Belanja Modal?

3. Apakah dana alokasi khusus (DAK) berpengaruh positif dan signifikan terhadap besarnya Belanja Modal? 
Tujuan penelitian ini adalah:

1. Untuk menganalisis dan membuktikan secara empiris seberapa besar pengaruh pendapatan asli daerah (PAD) terhadap Belanja Modal pada Pemerintah Daerah Kabupaten/Kota di Provinsi Sulawesi Utara.

2. Untuk menganalisis dan membuktikan secara empiris seberapa besar pengaruh dana alokasi umum (DAU) terhadap Belanja Modal pada Pemerintah Daerah Kabupaten/Kota di Provinsi Sulawesi Utara.

3. Untuk menganalisis dan membuktikan secara empiris seberapa besar pengaruh dana alokasi khusus (DAK) terhadap Belanja Modal pada Pemerintah Daerah Kabupaten/Kota di Provinsi Sulawesi Utara.

\section{Manfaat Penelitian}

Manfaat yang dapat diperoleh dalam penelitian ini sebagai berikut:

1. Bagi Instansi Pemerintahan, sebagai bahan masukan bagi pemerintah kabupaten/kota di Provinsi Sulawesi Utara untuk merealisasikan belanja modal, sehingga dapat meningkatkan pelayanan kepada masyarakat.

2. Bagi Akademisi, Hasil dari penelitian ini diharapkan dapat memberikan pandangan dan wawasan mengenai pengalokasian belanja modal.

\section{TINJAUAN PUSTAKA Landasan Teori \\ Teori Keagenan}

Carr dan Brower (2000), menyatakan model keagenan yang sederhana mengasumsikan dua pilihan dalam kontrak: (1) behavior-based, yakni perinsipal harus memonitor perilaku agen dan (2) outcomed based, yakni adanya insentif untuk memotivasi agen untuk mencapai kepentingan principal. Para teoritisi berpegang pada proposisi bahwa agents behave opportuniscally towards principals. Oportunisme bermakna bahwa ketika terjalin kerjasama antara principal dan agen, kerugian principal karena agen mengutamakan kepentingannya (agent self-interest) kemungkinan besar akan terjadi. Menurut Andvig et. al. (2001) principal agent model merupakan rerangka analitik yang sangat berguna dalam menjelaskan masalah insentif dalam institusi publik dengan dua kemungkinan kondisi yakni (1) terdapat beberapa prinsipal dengan masing-masing tujuan dan kepentingan yang tidak koheren dan (2) prinsipal juga bisa bertindak tidak sesuai dengan kepentingan masyarakat, tetapi mengutamakan kepentingannya yang lebih sempit.

\section{Akuntansi Pemerintah}

Menurut Indra Bastian (2007 : 15) akuntansi sektor publik dapat didefinisikan sebagai mekanisme teknis dan analisis akuntansi yang diterapkan pengelolaan dana masyarakat di lembaga-lembaga tinggi negara dan departemen-departemen di bawahnya, pemerintah daerah, BUMN, BUMD, LSM dan yayasan sosial, maupun pada proyek-proyek kerjasama sektor publik dan swasta. Menurut Nordiawan (2006:35) akuntansi sektor publik adalah proses pencatatan, pengklasifikasian, penganalisisan dan pelaporan transaksi keuangan dari suatu organisasi publik yang menyediakan informasi keuangan bagi para pemakai laporan keuangan yang berguna untuk pengambilan keputusan. Jadi akuntansi sektor publik dapat didefinisikan sebagai aktivitas jasa yang terdiri dari mencatat, mengklasifikasikan, dan melaporkan kejadian atau transaksi ekonomi yang akhirnya akan menghasilkan suatu informasi keuangan yang akan dibutuhkan oleh pihak-pihak tertentu untuk pengambilan keputusan, yang diterapkan pada pengelolaan dana publik di lembaga-lembaga tinggi negara dan departemen-departemen dibawahnya. 


\section{Otonomi Daearah}

Sujarweni (2015 : 230) menyatakan otonomi daerah merupakan kebebasan untuk mengambil keputusan politik maupun administrasi, dengan tetap menghormati peraturan perundang-undangan. Meskipun dalam otonomi daerah ada kebebasan untuk menentukan apa yang menjadi kebutuhan daerah, tetapi dalam kebutuhan daerah senantiasa disesuaikan dengan kepentingan nasional, ditetapkan dalam peraturan perundang-undangan yang lebih tinggi. Maryati dan Endrawati, (2010) menyatakan untuk menyelenggarakan otonomi daerah yang nyata dan bertanggung jawab diperlukan kewenangan dan kemampuan menggali sumber keuangan sendiri yang didukung oleh perimbangan keuangan antara pemerintah pusat dan daerah.

\section{Belanja Modal}

Menurut Halim \& Kusufi (2012 : 107) Belanja modal merupakan pengeluaran untuk perolehan aset lainnya yang memberikan manfaat lebih dari periode akuntansi. Belanja modal termasuk, 1) belanja tanah, 2) belanja peralatan dan mesin, 3) belanja modal gedung dan bangunan 4) belanja modal jalan, irigasi, dan jaringan, 5) belanja aset tetap lainnya. Menurut Halim (2007 : 101) belanja modal merupakan pengeluaran anggaran untuk perolehan aset tetap dan asset lainnya yang memberikan manfaat lebih dari satu periode akuntansi. Belanja modal dimaksudkan untuk mendapatkan aset tetap pemerintah daerah yaitu peralatan, bangunan, infrastruktur dan harta tetap lainnya. Menurut Peraturan Menteri Keuangan Nomor 91/PMK.06/2007 mendefinisikan belanja modal sebagai pengeluaran anggaran yang digunakan dalam rangka memperoleh atau menambah aset tetap dan aset lainnya yang memberi manfaat lebih dari satu periode akuntansi serta melebihi batasan minimal kapitalisasi aset tetap atau aset lainnya yang ditetapkan oleh pemerintah dimana aset tersebut dipergunakan untuk operasional kegiatan sehari-hari suatu satuan kerja bukan untuk dijual.

\section{Pendapatan Asli Daerah}

Menurut Darise (2007 : 43) berpendapat bahwa Pendapatan Asli Daerah adalah pendapatan yang diperoleh daerah yang dipungut berdasarkan peraturan daerah sesuai dengan peraturan perundang-undangan. Nurcholis (2007 : 182), menyatakan bahwa "pendapatan asli daerah adalah pendapatan yang diperoleh dari hasil pajak daerah, hasil retribusi daerah, laba perusahaan daerah, dan lain-lain yang sah. Halim (2007 : 96) menyatakan pendapatan asli daerah adalah penerimaan yang diperoleh daerah dari sumbersumber dalam wilayahnya sendiri yang dipungut berdasarkan peraturan daerah sesuai dengan peraturan perundang-undangan yang berlaku.yang bersumber dari pajak daerah, retribusi daerah, hasil pengelolaan kekayaan milik daerah yang dipisahkan, dan lain-lain PAD yang sah.

\section{Dana Alokasi Umum (DAU)}

Menurut Ahmad (2009: 142) Dana Alokasi Umum (DAU) adalah dana yang bersumber dari pendapatan APBN yang dialokasikan dengan tujuan pemerataan kemampuan keuangan antara daerah untuk menandai kebutuhan daerah dalam rangka pelaksanaan desentralisasi. Kuncuro (2004) menyatakan DAU bersifat "block grant" yang berarti penggunaanya diserahkan kepada daerah sesuai dengan prioritas dan kebutuhan daerah untuk penigkatan pelayanan kepada masyarakat dalam rangka pelaksanaan otonomi daerah. Dengan kata lain, tujuan alokasi DAU adalah dalam rangka pemerataan kemampuan peyediaan pelayanan publik antar pemerintah daerah di Indonesia. Dengan kata lain, tujuan alokasi DAU adalah 
dalam rangka pemerataan kemampuan penyediaan pelayanan publik antar pemerintah daerah di Indonesia.

\section{Dana Alokasi Khusus (DAK)}

Menurut Darise (2009: 91) dana alokasi khusus (DAK) adalah dana yang bersumber dari Pendapatan APBN yang dialokasikan kepada daerah tertentu dengan tujuan untuk membantu mendanai kegiatan khusus yang merupakan urusan daerah dan sesuai dengan prioritas nasional sesuai dengan fungsi yang telah ditetapkan dalam APBN. Sedangkan menurut Halim (2004: 65) dana alokasi khusus (DAK) adalah dana yang berasal dari anggaran pendapatan belanja negara yang dialokasikan kepada daerah untuk membiayai kebutuhan tertentu.

\section{KERANGKA KONSEPTUAL}

\section{Kerangka Konseptual Pemikiran}

Gambar 3.1 Kerangka Konseptual Pemikiran

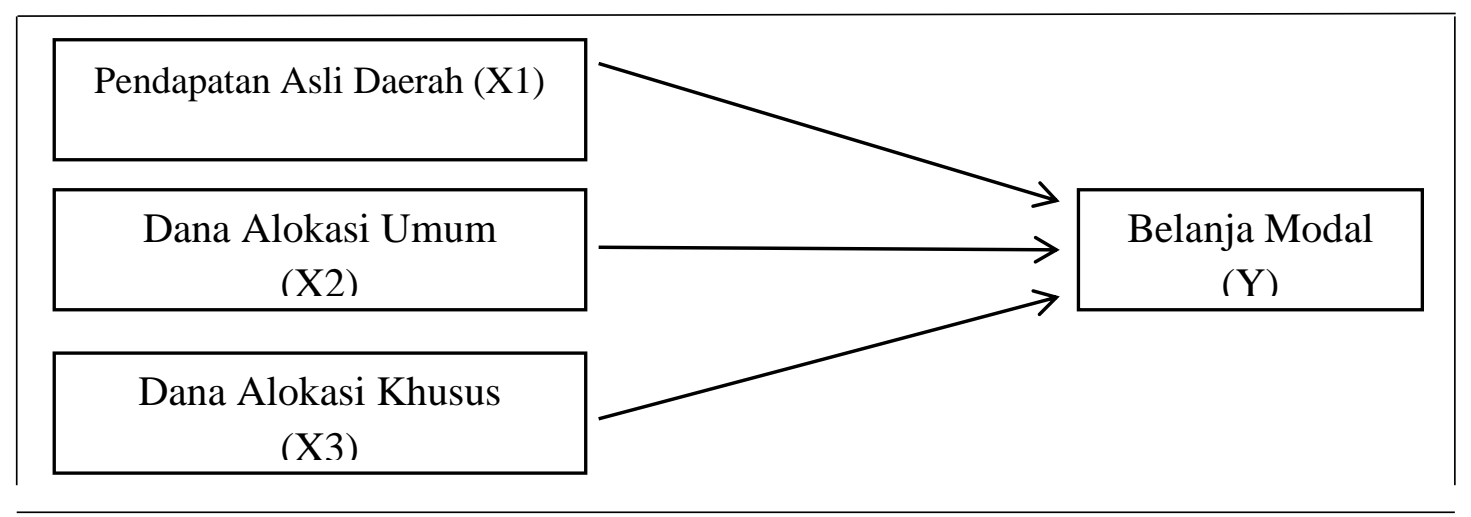

\section{Hipotesis Penelitian}

H1 : Pendapatan Asli Daerah (PAD) berpengaruh positif dan signifikan terhadap Belanja Modal.

H2 : Dana Alokasi Umum (DAU) berpengaruh positif dan signifikan terhadap Belanja Modal. H3 : Dana Alokasi Khusus (DAK) berpengaruh positif dan signifikan terhadap Belanja Modal.

\section{METODE PENELITIAN}

\section{Jenis/Rancangan Penelitian}

Penelitian Ilmiah ini adalah aplikasi secara formal dan sistematis dari metode ilmiah yang kritis, analisis, logis, objektif, konseptual, teoritis, empiris dan sistematis untuk mempelajari dan menjawab permasalahan dengan tujuan membuat penjelasan, menyusun prediksi, serta mengendalikan fenomena yang terjadi di dalam suatu batasan yang ditentukan (Kuncoro, 2009 : 2-4). Dalam penelitian ini penulis menggunakan metode penelitian Kuantitatif. Data yang diperoleh diwujudkan dalam bentuk angka, dan analisisnya menggunakan statistik

\section{Populasi Dan Sampel}

Populasi adalah jumlah dari keseluruhan objek-objek atau (satuan/individu) yang mempunyai karakteristik tertentu. Menurut Sugiyono (2012:80) populasi adalah wilayah generalisasi yang terdiri atas obyek atau subyek yang mempunyai kualitas dan karakteristik tertentu yang ditetapkan oleh peneliti untuk dipelajari dan kemudian ditarik kesimpulannya. Adapun populasi dalam penelitian ini adalah data Laporan Realisasi Anggaran Pendapatan Belanja Daerah Kabupaten dan Kota di Provinsi Sulawesi Utara. Yang meliputi 11 Kabupaten dan 4 Kota, jumlah populasi adalah 15 Pemerintah Daerah $\times 5$ Tahun $=75$. 
Arikunto (2013 : 174) menyatakan bahwa sampel adalah sebagian atau wakil populasi yang diteliti. Selanjutnya menurut Sugiyono (2012 : 81) sampel adalah bagian dari jumlah dan karakteristik yang dimiliki oleh populasi tersebut. Sampel yang digunakan dalam penelitian yaitu data PAD, DAU, DAK dan Belanja Modal Kabupaten dan Kota di Provinsi Sulawesi Utara. Penelitian ini mengambil semua populasi dijadikan sampel. Jadi jumlah sampel penelitian keseluruhan menjadi 5 × $15=75$ data.

\section{Jenis dan Sumber Data}

Sumber data yang digunakan dalam penelitian ini adalah data sekunder yang bersumber dari Laporan Realisasi APBD Pemda di Provinsi Sulawesi Utara, yakni data PAD, DAU, DAK dan Belanja Modal yang diperoleh dari Badan Pusat Statistik Pemerintah Provinsi Sulawesi Utara. Adapun data yang digunakan adalah data Laporan Realisasi APBD Kabupaten/Kota di Provinsi Sulawesi Utara Tahun 2011 sampai 2015.

\section{Teknik Analisis Data}

Pada penelitian ini, pengujian dilakukan dengan analisis regresi linier berganda, analisis regeresi berganda adalah analisis mengenai beberapa variabel independen dengan satu variabel dependen. Secara umum, analisis regresi adalah analisis mengenai variabel independen dengan variabel dependen yang bertujuan untuk mengistimasi nilai rata-rata variabel dependen berdasarkan nilai variabel independen yang diketahui (Gujarati, 2013).

1. Analisis Statistik Deskriptif

2. Analisis Regresi Berganda: $Y=\alpha+\beta 1 X 1+\beta 2 X 2+\beta 3 X 3+e$

3. Pengujian Asumsi Klasik

4. Pengujian Hipotesis

\section{HASIL PENELITIAN DAN PEMBAHASAN}

Analisis Statistik Deskriptif

Tabel 5.3

Descriptive Statistics

\begin{tabular}{|l|r|r|r|r|r|}
\hline & $\mathrm{N}$ & $\begin{array}{c}\text { Minimu } \\
\mathrm{m}\end{array}$ & $\begin{array}{c}\text { Maximu } \\
\mathrm{m}\end{array}$ & \multicolumn{1}{c|}{ Mean } & \multicolumn{1}{c|}{$\begin{array}{c}\text { Std. } \\
\text { Deviation }\end{array}$} \\
\hline PAD & 75 & 4844 & 275207 & 34588.31 & 52660.128 \\
DAU & 75 & 181719 & 750810 & 379496.53 & 117429.676 \\
DAK & 75 & 0 & 121138 & 51933.60 & 19374.945 \\
Belanja Modal & 75 & 62651 & 219307 & 131428.87 & 33568.694 \\
Valid N & 75 & & & & \\
(listwise) & & & & & \\
\hline
\end{tabular}

Sumber : Olah Data SPSS (Dalam Jutaan Rupiah)

1. Belanja Modal

Tabel 5.3 menunjukan hasil perhitungan dari statistik deskriptif, dimana nilai rata-rata untuk belanja modal adalah sebesar $\mathrm{Rp} 131.428,87$. Nilai maksimum dari belanja modal Pemerintah Daerah Provinsi Sulawesi Utara adalah sebesar Rp 219.307. Dan nilai minimum dari belanja modal Pemerintah Daerah Provinsi Sulawesi Utara adalah sebesar Rp 62.651.

\section{Pendapatan Asli Daerah}

Tabel 5.3 menunjukan hasil perhitungan dari statistik deskriptif, dimana nilai rata-rata untuk pendapatan asli daerah adalah sebesar Rp 34.588,31. Nilai maksimum dari pendapatan 
asli daerah Pemerintah Daerah Provinsi Sulawesi Utara adalah sebesar Rp 275.207. Dan nilai minimum dari pendapatan asli daerah Provinsi Sulawesi Utara Rp 4.844.

\section{Dana Alokasi Umum}

Tabel 5.3 menunjukan hasil perhitungan dari statistik deskriptif, dimana nilai rata-rata untuk dana alokasi umum adalah sebesar Rp 379.496,53. Nilai maksimum dari dana alokasi umum Pemerintah Daerah Provinsi Sulawesi Utara adalah sebesar Rp 750.810. Dan nilai minimum dari dana alokasi umum Pemerintah Daerah Pemerintah Daerah Provinsi Sulawesi Utara adalah sebesar Rp 181.719.

\section{Dana Alokasi Khusus}

Tabel 5.3 menunjukan hasil perhitungan dari statistik deskriptif, dimana nilai rata-rata untuk dana alokasi khusus adalah sebesar Rp 51.933,60. Nilai maksimum dari dana alokasi khusus Pemerintah Daerah Provinsi Sulawesi Utara adalah sebesar Rp 121.138. Dan nilai minimum dari dana alokasi khusus Pemerintah Daerah Provinsi Sulawesi Utara adalah sebesar Rp 0.

\section{Analisis Regresi Berganda}

Tabel 5.4

Hasil Analisis Regresi Berganda

\begin{tabular}{|c|c|c|c|c|c|c|}
\hline \multirow{2}{*}{\multicolumn{2}{|c|}{ Model }} & \multicolumn{2}{|c|}{$\begin{array}{l}\text { Unstandardized } \\
\text { Coefficients }\end{array}$} & \multirow{2}{*}{$\begin{array}{c}\text { Standardized } \\
\text { Coefficients } \\
\text { Beta }\end{array}$} & \multirow[b]{2}{*}{$\mathrm{t}$} & \multirow[b]{2}{*}{ Sig. } \\
\hline & & B & Std. Error & & & \\
\hline \multirow[t]{4}{*}{1} & (Constant) & 107789.219 & 14603.244 & & 7.381 & .000 \\
\hline & PAD & .383 & .106 & .600 & 3.595 & .001 \\
\hline & DAU & -.028 & .051 & -.096 & -.538 & .593 \\
\hline & DAK & .401 & .197 & .232 & 2.034 & .046 \\
\hline
\end{tabular}

a. Dependent Variable: Belanja Modal

Sumber : Olah Data SPSS

Hasil estimasi model regresi berganda dapat ditulis sebagai berikut:

$$
Y=107789.219+0.383 \times 1-0.028 \times 2+0.401 \times 3+e
$$

Persamaan tersebut dapat diartikan :

Variabel PAD (X1) menunjukkan ada pengaruh terhadap Belanja Modal dan berpola positif sehingga semakin bertambah PAD maka semakin tinggi Belanja Modal. Jadi jika PAD (X1) meningkat sebesar satu satuan sedangkan variable lainnya tetap, maka akan mengakibatkan naiknya nilai variabel Belanja Modal $(Y)$ sebesar 0.383 satuan.

Variabel DAU (X2) menunjukkan ada pengaruh terhadap Belanja Modal dan berpola negatif sehingga semakin bertambah DAU maka semakin rendah Belanja Modal. Jadi apabila DAU (X2) meningkat satu satuan sedangkan variable lainnya tetap, maka akan mengakibatkan turunnya nilai variabel Belanja Modal sebesar 0.028 satuan.

Variabel DAK (X3) menunjukkan ada pengaruh terhadap Belanja Modal dan berpola positif sehingga semakin bertambah DAK maka semakin tinggi Belanja Modal. Jadi apabila DAK (X3) meningkat satu satuan sedangkan variabel lainnya tetap, maka akan mengakibatkan naiknya nilai variabel Belanja Modal (Y) sebesar 0,401 satuan.

\section{Pengujian Asumsi Klasik}




\title{
Uji Normalitas
}

Tabel 5.5

One-Sample Kolmogorov-Smirnov Test

\begin{tabular}{|ll|r|}
\hline & & $\begin{array}{r}\text { Unstandardiz } \\
\text { ed Residual }\end{array}$ \\
\hline $\mathrm{N}$ & & 75 \\
Normal Parameters & Mean & .0000000 \\
& Std. & 27479.75639 \\
& Deviation & 628 \\
Most Extreme & Absolute & .059 \\
Differences & Positive & .059 \\
& Negative & -.045 \\
Test Statistic & & .059 \\
Asymp. Sig. (2-tailed) & & $.200^{\mathrm{c}, \mathrm{d}}$ \\
\hline
\end{tabular}

a. Test distribution is Normal.

b. Calculated from data.

Sumber : Olah Data SPSS

Pengujian normalitas melalui kolmogorov smirnov adalah dengan cara hasil data menunjukkan bahwa probabilitas pengujian di atas 0,05. Hasil uji normalitas pada tabel $5.5 \mathrm{di}$ atas didapatkan nilai signifikansi dari Uji K-S sebesar 0,200. Angka tersebut lebih tinggi dibandingkan dengan taraf signifikansi 5\% (0.05). Hal tersebut memberikan gambaran bahwa sebaran data tidak menunjukkan penyimpangan dari kurva normalnya, yang berarti bahwa sebaran data telah memenuhi asumsi normalitas.

\section{Uji Multikolinieritas}

Tabel 5.6

Uji Multikolonieritas

\begin{tabular}{|c|c|c|c|}
\hline \multirow{2}{*}{\multicolumn{2}{|c|}{ Model }} & \multicolumn{2}{|c|}{$\begin{array}{c}\text { Collinearity } \\
\text { Statistics }\end{array}$} \\
\hline & & Tolerance & VIF \\
\hline \multirow[t]{3}{*}{1} & PAD & .338 & 2.956 \\
\hline & DAU & .294 & 3.400 \\
\hline & DAK & .727 & 1.375 \\
\hline
\end{tabular}

a. Dependent Variable: Belanja

Modal

Sumber : Olah Data SPSS

Berdasarkan Tabel 5.6 hasil perhitungan nilai tolerance memperlihatkan bahwa masing-masing variabel independen (PAD, DAU dan DAK) tidak ada yang memiliki nilai kurang dari 0.10 yang berarti tidak ada korelasi antar variable independen. Hasil perhitungan nilai VIF juga menunjukkan bahwa nilai VIF masing-masing variabel tidak memiliki nilai yang lebih dari 10.00 sehingga dapat disimpulkan bahwa tidak ada multikolinieritas antar variable independen.

\section{Uji Heteroskedastisitas}

\author{
Gambar 5.2
}




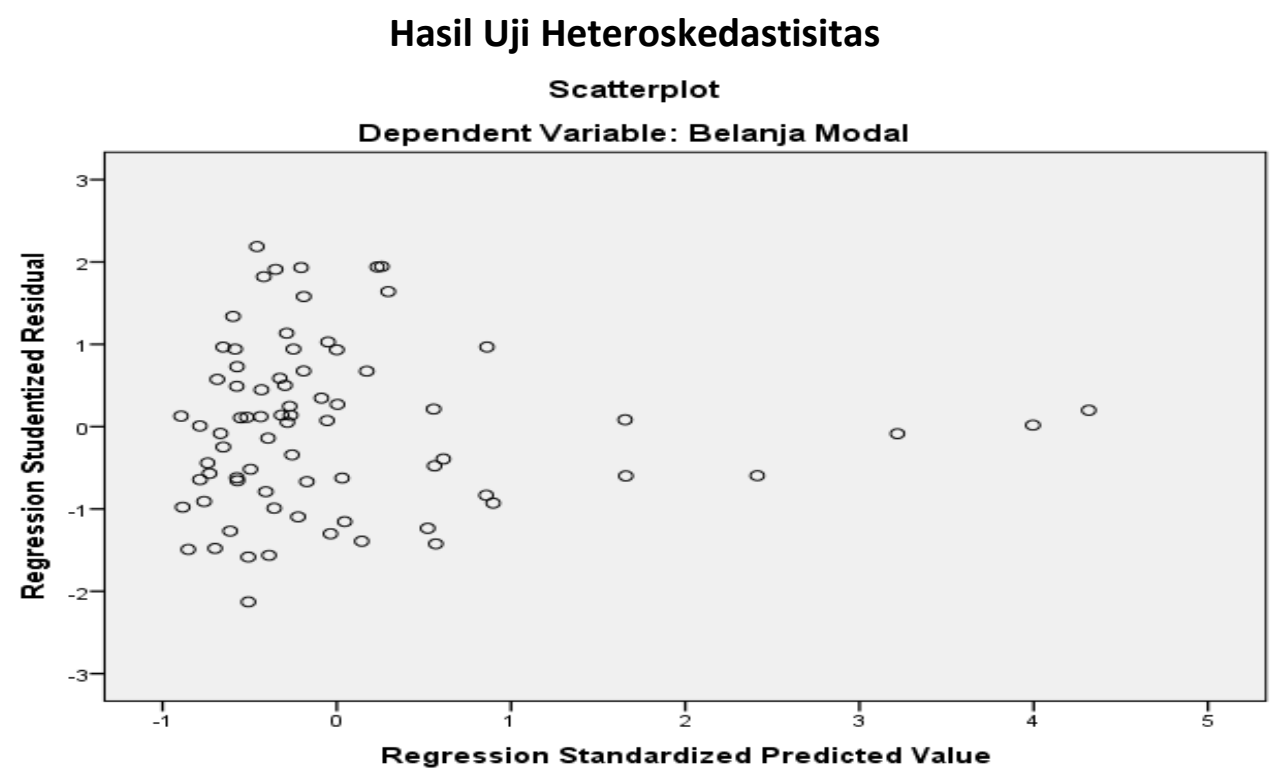

Sumber : Olah Data SPSS

Hasil Scatterplot Model pada gambar 5.2 diatas dapat diketahui bahwa tidak ada pola yang jelas, serta titik-titik menyebar diatas dan dibawah angka 0 pada sumbu $Y$, maka tidak terjadi Heteroskedastisitas.

\section{Pengujian Hipotesis \\ Uji t (Uji Parsial)}

Tabel 5.7

Uji t (Parsial)

\begin{tabular}{|c|c|c|c|c|c|c|}
\hline \multirow{2}{*}{\multicolumn{2}{|c|}{ Model }} & \multicolumn{2}{|c|}{$\begin{array}{c}\text { Unstandardized } \\
\text { Coefficients }\end{array}$} & \multirow{2}{*}{$\begin{array}{c}\begin{array}{c}\text { Standardized } \\
\text { Coefficients }\end{array} \\
\text { Beta }\end{array}$} & \multirow[b]{2}{*}{$\mathrm{t}$} & \multirow[b]{2}{*}{ Sig. } \\
\hline & & B & Std. Error & & & \\
\hline \multirow[t]{4}{*}{1} & (Constant) & 107789.219 & 14603.244 & & 7.381 & .000 \\
\hline & PAD & .383 & .106 & .600 & 3.595 & .001 \\
\hline & DAU & -.028 & .051 & -.096 & -.538 & .593 \\
\hline & DAK & .401 & .197 & .232 & 2.034 & .046 \\
\hline
\end{tabular}

a. Dependent Variable: Belanja Modal

Sumber : Olah Data SPSS

Hipotesis pertama yang diajukan adalah pendapatan asli daerah (PAD) berpengaruh positif dan signifikan terhadap belanja modal. Berdasarkan hasil perhitungan statistik dari table diatas dapat dilihat PAD mempunyai t signifikasi 0,001 . Karena t signifikasi $0,001<$ dari $\alpha$ yang ditentukan yaitu 0,05 , maka hipotesis diterima dan pendapatan asli daerah (PAD) berpengaruh positif dan signifikan terhadap belanja modal.

Hipotesis kedua yang diajukan adalah dana alokasi umum (DAU) berpengaruh positif dan signifikan terhadap belanja modal. Berdasarkan hasil perhitungan statistik dari table diatas dapat dilihat dana alokasi umum (DAU) mempunyai $t$ signifikasi 0,593. Karena $t$ signifikasi 0,593 > dari $\alpha$ yang ditentukan yaitu 0,05 , maka hipotesis ditolak. Sehingga tidak ada pengaruh dana alokasi umum (DAU) terhadap belanja modal.

Hipotesis ketiga yang diajukan adalah dana alokasi khusus (DAK) berpengaruh positif dan signifikan terhadap belanja modal. Berdasarkan hasil perhitungan statistik dari table diatas dapat dilihat $\mathrm{t}$ signifikasi $0,046<$ dari $\alpha$ yang ditentukan yaitu 0,05 maka hipotesis 
diterima dan dana alokasi khusus (DAK) berpengaruh positif dan signifikan terhadap belanja modal.

Uji F (Uji Simultan)

Tabel 5.8

Uji F (Simultan)

\begin{tabular}{|c|c|c|c|c|c|c|}
\hline \multicolumn{2}{|c|}{ Model } & $\begin{array}{l}\text { Sum of } \\
\text { Squares }\end{array}$ & $\mathrm{df}$ & Mean Square & $\mathrm{F}$ & Sig. \\
\hline \multirow[t]{3}{*}{1} & Regression & $2.751 E+10$ & $\overline{3}$ & 9169098567 & 11.650 & $.000^{b}$ \\
\hline & Residual & $5.588 E+10$ & 71 & 787044209.3 & & \\
\hline & Total & $8.339 E+10$ & 74 & & & \\
\hline
\end{tabular}

a. Dependent Variable: Belanja Modal

b. Predictors: (Constant), DAK, PAD, DAU

Sumber : Olah Data SPSS

Tabel 5.8 menunjukkan hasil perhitungan statistik uji $\mathrm{F}$ dengan hasil nilai signifikansi $\mathrm{F}$ sebesar 0,000 di bawah 0,05 yang berarti Ha diterima, secara simultan seluruh variable independen yaitu pendapatan asli daerah (PAD), dana alokasi umum (DAU) dan dana alokasi khusus (DAK) berpengaruh positif dan signifikan terhadap variable belanja modal.

\section{Koefisien Determinasi}

Tabel 5.9

Koefisien Determinasi

\begin{tabular}{|l|c|r|r|r|}
\hline Model & $\mathrm{R}$ & R Square & $\begin{array}{c}\text { Adjusted R } \\
\text { Square }\end{array}$ & $\begin{array}{c}\text { Std. Error of } \\
\text { the Estimate }\end{array}$ \\
\hline 1 & $.574^{\mathrm{a}}$ & .330 & .302 & 28054.308 \\
\hline
\end{tabular}

a. Predictors: (Constant), DAK, PAD, DAU

b. Dependent Variable: Belanja Modal

Sumber : Olah Data SPSS

Berdasarkan hasil perhitungan koefisien determinasi pada tabel 5.9, diperoleh nilai koefisien determinasi yang disesuaikan (adjusted $R$ Square ) adalah 0,302 artinya 30,2\% variasi dari semua variable bebas (PAD, DAU dan DAK) dapat menerangkan variable terikat (tingkat materialistas), sedangkan sisanya sebesar 0,698 $(69,8 \%)$ diterangkan oleh variabel lain yang tidak diajukan dalam penelitian ini.

\section{Pembahasan}

\section{Pengaruh Pendapatan Asli Daerah terhadap Belanja Modal}

Hasil penelitian yang telah dilakukan, diperoleh hasil bahwa variabel pendapatan asli daerah (PAD) secara parsial berpengaruh positif dan signifikan terhadap variabel belanja modal. Hal ini ditunjukkan dengan tingkat signifikansi 0,001 lebih kecil dari $\alpha 0,05$. Temuan hasil penelitian ini berarti pendapatan asli daerah (PAD) secara langsung berperan positif atau meningkatkan belanja modal pada Pemerintah Kabupaten/Kota di Provinsi Sulawesi Utara.

\section{Pengaruh Dana Alokasi Umum terhadap Belanja Modal}

Hasil penelitian yang telah dilakukan, diperoleh hasil bahwa variabel Dana Alokasi Umum (DAU) secara parsial tidak berpengaruh terhadap variabel belanja modal. Hal ini ditunjukkan dengan tingkat signifikansi 0,593 lebih besar dari $\alpha$ 0,05. Artinya dana alokasi 
umum (DAU) tidak memiliki pengaruh yang nyata terhadap belanja modal, karena Pemerintah Daerah Kabupaten/Kota di Provinsi Sulawesi Utara tidak memiliki belanja modal yang besar, Pemerintah Daerah Kabupaten/Kota di Provinsi Sulawesi Utara lebih cenderung menggunakan DAU untuk belanja yang lain, seperti belanja pegawai, belanja barang dan jasa dan belanja lainnya.

\section{Pengaruh Dana Alokasi Khusus terhadap Belanja Modal}

Hasil penelitian yang telah dilakukan, diperoleh hasil bahwa variabel dana alokasi khusus (DAK) secara parsial berpengaruh positif dan signifikan terhadap variable belanja modal. Hal ini ditunjukkan dengan tingkat signifikansi 0,046 lebih kecil dari $\alpha 0,05$. Artinya DAK memiliki pengaruh yang nyata terhadap belanja modal. Hasil ini menjelaskan bahwa Jika Pemerintah Daerah Kabupaten/Kota di Provinsi Sulawesi Utara mendapatkan DAK yang besar maka akan cenderung memiliki belanja modal yang besar pula.

\section{Pengaruh Pendapatan Asli Daerah, Dana Alokasi Umum, dan Dana Alokasi Khusus terhadap Belanja Modal}

Hasil penelitian secara simultan, menunjukkan bahwa variabel PAD, DAU dan DAK berpengaruh positif dan signifikan terhadap belanja modal yang dijelaskan oleh nilai $F$ signifkasi 0,000 berada dibawah 0,05. Hal ini berarti belanja modal pada Pemerintah Daerah Kabupaten/Kota di Provinsi Sulawesi Utara ditentukan oleh PAD, DAU dan DAK, yakni terlihat dari koefisien determinasi sebesar 30,2 \% dan selebihnya 69,8\% ditentukan oleh variabel lain yang tidak diajukan dalam penelitian ini.

\section{KESIMPULAN DAN SARAN \\ Kesimpulan}

Berdasarkan hasil penelitian dan pembahasan yang telah dilakukan sebelumnya maka dapat diambil kesimpulan dalam penelitian ini sebagai berikut :

1. Pengujian secara parsial menunjukan bahwa terdapat pengaruh yang positif dan signifikan antara variabel pendapatan asli daerah (PAD) terhadap pengalokasian Belanja Modal.

2. Pengujian secara parsial menunjukan bahwa tidak terdapat pengaruh signifikan antara variabel dana alokasi umum (DAU) terhadap pengalokasian Belanja Modal.

3. Pengujian secara parsial menunjukan bahwa terdapat pengaruh yang positif dan signifikan antara variabel dana alokasi khusus (DAK) terhadap pengalokasian Belanja Modal.

4. Pengujian secara simultan variabel Pendapatan Asli Daerah, Dana Alokasi Umum, dan Dana Alokasi Khusus, berpengaruh positif terhadap pengalokasian Belanja Modal dengan koefisien determinasi $30,2 \%$, dan selebihnya $69,8 \%$ di pengaruhi oleh faktor lain di luar model penelitian ini.

Saran

1. Pemerintah Daerah Provinsi Sulawesi Utara kedepannya diharapkan lebih meningkatkan proporsi dana alokasi umum (DAU) terhadapat pengalokasian belanja modal.

2. Pemerintah Daerah Provinsi Sulawesi Utara hendaknya mengurangi aktivitas belanja pegawai, dan belanja barang dan jasa dan lebih meningkatkan aktivitas belanja modalnya. 
3. Untuk penelitian selanjutnya, sebaiknya menggunakan rentang waktu penelitian yang lebih panjang agar memperoleh hasil yang lebih relevan.

4. Penambahan variabel baru sebagai variabel independen maupun variabel dependen sangat penting untuk melengkapi hasil penelitian terdahulu.

\section{DAFTAR PUSTAKA}

Ahmad Yani, 2009. Hubungan Keuangan antara Pemerintah Pusat dan Daerah di Indonesia. Jakarta : PT. RajaGrafindo Persada.

Andvig, Jens Chr, Odd-Helge Fjeldstad, Inge Amundsen, Tone Sissener \& Tina Soreide. 2001. Corruption A Review Of Contemporary Research. Chr. Michelsen Institute Development Studies and Human Rights Report $R$ 2001: 7. Web: http//www. Cmi.no.

Arikunto, Suharsimi. 2013. Prosedur Penelitian : Suatu Pendekatakan Praktik. Cetakan Kelimabelas. Jakarta : Rineka Cipta.

Bastian, Indra. 2006. Akuntansi Sektor Publik: Suatu Pengantar. Jakarta: Erlangga

Carr, Jared B, \& Ralph S. Brower. 2000. Principled Opportunism: Envidence From The Organizational. Public Administration Quarterly (Spring): 109-138.

Darise. Nurlan. 2007. Pengelolaan Keuangan Daerah. Jakarta: PT. Indeks.

Gujarati, Damodar. 2013. Dasar-Dasar Ekonometrika. Edisi 5 Buku 2. Jakarta : Salemba Empat. Halim, Abdul. 2004. Akuntansi Keuangan Daerah. Jakarta: Salemba Empat.

Darise, Nurlan. 2009. "Pengelolaan Keuangan Daerah". Edisi Kedua. PT. Indeks. Jakarta.

Halim, Abdul. 2007. Akuntansi Sektor Publik Akuntansi Keuangan Daerah. Jakarta: Salemba Empat.

Halim dan Kusufi. 2012. Akuntansi Sektor Publik: "Akuntansi Keuangan Daerah:. Jakarta: Salemba Empat.

Kawendar, Warsito, Rohman Abdul, Handayani Sri. 2008. Akuntansi Sektor Publik. Semarang: Universitas Diponegoro.

Kuncoro, Mudrajat. 2004. Otonomi dan Pembangunan Daerah: Reformasi, Perencanaan, Strategi dan Peluang. Jakarta: Erlangga.

Kuncoro, Mudrajat. 2009. Metode Riset untuk Bisnis dan Ekonomi. Edisi Ketiga, Penerbit : Erlangga, Jakarta.

Mardiasmo. 2009. Akuntansi Sektor Publik. Penerbit Andi. Yogyakarta.

Maryati dan Endrawati. 2010. Pengaruh Pendapatan Asli Daerah (PAD), Dana Alokasi Umum (DAU) dan Dana Alokasi Khusus (OAK) Tehadap Pertumbuhan Ekonomi: Studi Kasus Sumatera Barat. ISSN 1858-3687 Jumal Akuntansi \& Manajemen Vol 5 No.2 : 68-84

Nurcholis, Hanif. 2007. Teori dan Praktek Pemerintah dan Otonomi daerah, Edisi Revisi. Jakarta: Grasindo.

Nordiawan, Deddi. 2006. Akuntansi Sektor Publik. Salemba Empat. Jakarta.

Republik Indonesia. 2007. Peraturan Menteri Keuangan No. 91/PMK.06/2007 tentang Bagan Akun Standar. Jakarta: Indonesia.

Republik Indonesia. 2010. PP Nomor 71 Tahun 2010, tentang Standar Akuntansi Pemerintahan. Jakarta: Indonesia.

Sugiyono. 2012. Statistika Untuk Penelitian. Bandung : ALFABETA.

Sujarweni, Wiratna. 2015. Akuntansi Sektor Publik. Penerbit : Pustaka Baru Press. Yogyakarta. 